\title{
Supply Response of Potato to Price and Non-price factors in Swaziland
}

\author{
D. V. Dlamini \\ Department of Agricultural Economics and Management, \\ Faculty of Agriculture of the University of Swaziland
}

\begin{abstract}
This study analyzed the supply response of potato to price and non-price factors in Swaziland using econometrics techniques. An improved Nerlovian adjustment model was applied on the historical time series data spanning from 1986-2016 and VECM to estimate the acreage supply response of potato to price and no-price factors. And the model was used to estimate the supply response and to estimate the short and long run elasticity's of price. The results showed that the price change of potato and substitute crop price are positive and significant which implies that farmers respond positively to a change in price in the short run but in the long run it is not significant because of the uncertainties of its markets. Rainfall is not significant to supply of potato in the short run because potato are irrigated crops but in the long run they may have a positive impact as farmers can be able to use the water that comes from the rainfall. However, the sustainability of potato production is paramount to the supply response of the product. Therefore, needed inputs such as credit facilities and subsidized planting materials should be made available to the farmers and the government and various stakeholders must work tireless to try and develop the markets of sweet potato in order to be sustainable so that farmers must be able to respond to sweet potato price increase even in the long run without any fear of risk, because of the uncertainty of the markets.
\end{abstract}

Keywords: Nerlovian, Potato, Price and Non-price factor, Supply response, Yield

\section{INTRODUCTION}

Agriculture belongs to the real sector of Swazi Economy. Agriculture provides primary means of employment for Swazis and account for more than -one third of the total gross domestic product (GDP) and labour force (Xaba 2012). The agricultural sector of Swaziland is split between a largely rain-fed subsistence production by smallholders established on the Swazi Nation land (SNL) and cash cropping established on large private estates. Agriculture on the Title deed Land (TDL) takes about $40 \%$ of the land, while the rest is occupied by the traditional sub-sector (Dlamini, 2012).

The potato are one of the most respected food crops in the world with annual production volume of 347 metric million tonnes, produced in an estimated area of 18.9 million hectares (FAOSTAT, 2014). Potatoes are ranked fourth in the world as food crop after maize, wheat and rice. Between roots crops, potatoes are ranked first in terms of volume produced and consumed followed by cassava, sweet potato and yams, and offers half of the world's annual yield of all roots and tubers (FAOSTAT, 2004). It is the biggest, non-cereal crop world-wide and it contribute energy and substantial amounts of high quality of proteins (Horton, 1987).

Potatoes offer more nutritious food per unit land in less time and often under more hostile conditions than other food crops (Hall, 2008). It is one of the most competent crops in converting natural resources, labour and capital into a high quality food with wide consumer acceptance (FAO, 2006). Potatoes are important crops in emerging countries because they can be used as a chief meal and as a stable source of income (FAO, 2006). More than one-third of 
the worldwide potato output comes from emerging countries including Asia (China, India, Indonesia, Nepal, Pakistan countries) and Africa (Cameroon, South Africa, Kenya, Uganda, Egypt, Algeria, Morocco, and Tanzania) (Bonabana-Wabbi). The consumption of potatoes in emerging countries increased from 9kg per capita in 1961-63 to $14 \mathrm{~kg}$ per capita in 1995-97. Main producing countries in Africa are Egypt, Algeria, South Africa and Morocco, which produces $65 \%$ of the total world production (Okoboi, 2010). According to Mdluli (2014), potato production in Swaziland is outshined by sweet potatoes production, which is being produced in bulky quantities in the low yield as many growers in that region are being stimulated to produce the sweet potatoes. This may be due to the fact that sweet potatoes want less water and has less input costs likened to potatoes.

Supply response of crops is one of the most imperative cases in agricultural growth economic this is because the responsiveness of farmers to economic motivation regulates agriculture contribution to the economy where the sector is the largest employer of labor. The agricultural policies play a vital in increasing farm production Rahji 2008). The Supply response is vital to an understanding of this price mechanism Nerlove and (1960). Again, the development of this production that while effective in recent year, may be relatively hard to be repeated in the future Anonymous, (2008). This is due to the economic crisis and for financial challenges which results in reduced subsidies for this activity with these conditions, some area of Agricultural policy experts interested in observing the response supply and demand for input in rice farming.

Despite efforts to stimulate potato production in the country through the potato seed plant program and the higher prices with the stable market stable for potato which aim to give the Swazi producers a motivation to stimulate the production of potato in the country. The production of potato in the country has been under normal and has been growing by minor margins, at an average of about $2 \%$ annually (Fact fish, 2014). Swaziland produced about 8220 tons of potatoes in 2014 , of which that quantity make about $20 \%$ of the local demand with rest being imported from South Africa (Fact fish, 2016, NAMBOARD, 2012), it evident that the country still has a shortage of potato production.

Also with the available seed plant program and higher prices for potatoes, the farmers still fail to produce sufficient potato for the country demand. It evident that the high price of potatoes which aim to motivate the farmers to increase the potato production has not worked, while input prices and other non-price factors influence farm production. In addition to that the Swazi farmer's acreage supply response of potato to price and non-price factors is not known. Few research works has been conducted on acreage response of potato (Dawson 2002). Thus there is an intense need to study the production response of potato growers to price and nonprice factors in Swaziland to give an insight to policy makers for allocation of land and production of potato in Swaziland. Therefore, this study set to; estimate the trend analysis in acreage response over the years in Swaziland; estimate the responsiveness of potato farmers to price and non-price factors and determines the short and long- run price elasticity's of potato supply in Swaziland

\section{NERLOVIAN MODEL}

Braulk, (1982) reported that the Nerlovian model is most powerful and prosperous, witnessed by a large number of studies which used this approach and it also tells us that the Nerlovian model of all the econometrics models us to estimate agricultural supply response. The Nerlovian model is dynamic model explaining that output is a function of expected price, output (area) adjustment, and some exogenous variables. Moreover a model is defined as dynamic if the time path of the dependent autoregressive model because it includes lagged 
values of the dependent variable (output) among it includes lagged values of the dependent variable (output) said Gujarati, (1995).

Nerlovian anticipation model enables the analysis of both the speed and level of adjustment of actual acreage towards desired. Nerlovian in his ground-breaking work introduced elements of expectations and adjustment lags in producer's decision making process, thereby making it possible to differentiate between the short and long run effects of price changes on supply elasticities. Nerlov's work gave now lead in the field of agricultural supply models by presenting distributed lags in supply models. This approach presented more truthful assumption that farmers do not make full adjustments promptly, instead they distribute their adjustment among future periods till they approach some finest position.

The supply elasticities centered on a model assuming certain characteristics of price expectations of farmers and uncertainty about price expectations would explain why the use of distribution lags in response function becomes necessary. It explains the data better by yielding coefficients which are more reasonable in sign and magnitude and thereby providing better estimates of supply elasticities. It eliminates or reduces appreciable the danger of serial correlations in the residuals.

\section{METHODOLOGY}

The study used a time series data for a period of 30 years from (1986-2016). The data was provided by FAO, Swaziland Meteorological Department and Namboard. The data for Production, Area Harvested and Prices was obtained from FAO and the Rainfall was taken from the Swaziland Meteorological Department. The data for prices were not available in the database in Swaziland so we used proxy prices in South Africa. The variables that were used are dependents variables which are Area harvested and Production which were measured in tonnes/hectare and for independent variables are Prices of potatoes and sweet potato which are measured in Rand/tonne, rainfall which is measured in millimeters which were average for a year and was taken from the rainy season between October - March. The following statistical tools were used to analyze the collected data, taking into account the two objectives which are supply response and short and long run price elasticities. And the data was analyze with the aid of STATA software.

\section{Estimating Supply response of potato's}

It is to estimate the impact of supply response of Potato to price and non-price factors using the acreage response model. The benefits of utilizing pooled cross-sectional time series data over the others is well known, which include valuable information about diversity of attributes because the data contain both interregional and temporal variation and the detailed information about the data used is presented in the relevant section.

$$
\operatorname{LnArea}_{p t}=b_{0}+b_{1} \operatorname{Lnp}_{p}+b_{2} \operatorname{Lnp}_{p(t-1)}+b_{3} \operatorname{Lny_{p(t-1)}}+b_{4} \operatorname{LnR}(t-1)+5 \operatorname{Ln} A_{p(t-1)}+e_{t}
$$

Where:

Area $a_{p t}=$ Area of potato under cultivation in time

$P_{P}=$ potato price (Emalangeni $/ \mathrm{kg}$ ).

$P_{p(t-1)}=$ One year lag price of potato (Emalangeni $/ \mathrm{kg}$ )

$Y_{p(t-1)}=$ yield of potato with one year lag (ton/Emalangeni)

$R_{t-1}=$ Average rainfall in $\mathrm{mm}$ with one year

$A_{p\{t-1)}=$ Area under potato with one year lag

$e_{t}=$ stochastic error term

$\ln =$ Natural $\log$ 


\section{Estimation of short run and long run elasticities}

The coefficients of log model give short run elasticities of the corresponding variables. The long run elasticity can be derived as follows:

Where:

$$
L r=S / \lambda
$$

$\mathrm{Lr}=$ long run elasticity

$\mathrm{Sr}=$ short run elasticity

$\Lambda=$ coefficient of lagged dependent variable

$\lambda$ is greater than 0 but less than 1

\section{Testing for Unit roots non-stationarity}

In order to figure supply elasticities, relevant tests are done beforehand to avoid spurious regression results and unstable models. The time series data of the selected variables first have to be tested for unit roots. The Augmented Dickey Fuller test was performed on each of the logarithmic series of potato prices, potato area harvested, potato yield and rainfall to find out whether they contained a unit root.

The null hypothesis $\mathrm{H} 0: \emptyset=0$ (unit root) was tested with the alternative hypothesis specified as H1: $\emptyset<0$ (time series is stationary). The decision rule that guided the test required that the null hypothesis be rejected only if the Augmented Dickey Fuller statistic < MacKinnon critical values.

\section{RESULTS AND DISCUSSION}

Table 1 showed the statistical properties of the data employed in the supply of potato to price and non-price factors. The mean, standard deviation, maximum and minimum of the variables of the model are outlined for the specified time frame. On average, 6557.88 tonnes/hectare of potato are produced yearly with an average standard deviation of 730.24 tonnes/hectare. The average real producer price of potato is E98.36/tonne with a standard deviation of E46.94/tonne. The average potato acreage is 3274.25 hectares with a standard deviation of 284.52 hectares. The average annual rainfall is $138.99 \mathrm{~mm}$ with a standard deviation of 31.41 mm per year.

Table 1: Statistical properties of original data

\begin{tabular}{|l|l|l|l|l|}
\hline Variables & Mean & Std.Dev & Minimum & Maximum \\
\hline Area Harvested (t/ha) & 3274.25 & 284.52 & 2800 & 3800 \\
\hline Production (t) & 6557.88 & 730.24 & 5200 & 8200 \\
\hline Price of potato (E) & 98.36 & 46.94 & 31.39 & 183.22 \\
\hline Price Sweet potato (E) & 121.45 & 100.94 & 33.24 & 434.74 \\
\hline Rainfall & 138.99 & 31.41 & 60.30 & 93.71 \\
\hline
\end{tabular}

Note: All figures were rounded off to 2 decimal places

Figure 1 revealed that total area of potato crop during the study period rated to an average of 3274.25 tons/hectare, with the maximum fluctuating in the area of 3800 tons/hectare in 2005, the minimal area being 2800 in 1999 . The rise in cultivated areas for this crop can be credited increase in prices of potatoes which motivated the farmers to increase the area planted for potato because they want to maximize their profits and they responded by increase the area in order to increase the production of potato. The technological improvements can also have a positive effect on the area allocation, like if a new hybrid seed is introduced farmers will be encouraged to increase the area as they know that they will get a pumper harvest and make 
increase profits on the potato. and institutional frameworks and the Swaziland government seed plants program, while the fall of areas notices in 1999 is because of reducing prices of potato, the farmers responded by reducing the area allocation to potato production, because profits will not be maximized and also marks production to being very susceptible to technical and climatic factors, and the increase in the price of substitute crop will caused the farmers to shift their resources to the production of the sweet potato as it profitable to do that. And, again prices act as major incentives for farmers to make decisions to increase the area allocation, if the prices are favorable and it is very easy for the farmers to react to area allocation because they have greater control over it than the other variables, if they want to stimulate the production. And in 2005 towards 2014 we have seen a great improvement area allocation which means that the production area was exploited to increase production, it can due to the fact that prices are good on the market, the consumption of potato is escalating throughout the years, hence farmers need to increase the production to meet the market demand and technological improvement adoption of new varieties. In 2006 we seen a drop these may be due to the decline in prices and farmers, reduced their area allocation and allocate to substitute crop that was offering better prices. The results confirms (Mamingi, 1997) which stated that agricultural supply mostly in the system of area expansion is resolute by agricultural price and non-price factors.

\section{Production of potato (yield)}

Figure 1 display that potato crop production in Swaziland during the study period average to 65557.88 tons. Interestingly, there was a slightly increase during 1991-2014 because the increasing measures. The highest level production was in 2013 which was 8200 tons in contrast with the minimum level in 1999 being 5200 tons. The graphs show that potato production has been displaying a fluctuation trend, an increase in some years and a decrease in some years and from 2000 to 2014 the production was increasing at a decreasing rate. The highest production was in 2013, it was due to the increasing the land used for planting of potato soon, but, the level of production declined in 2006 to reach 5200 tons, these may because of reduced of area planted in 2006 and the drop of potato prices which demotivated the farmers to be less interested to invest more resources such as area allocated to the potato production because their profits will not be maximized to increased their production due to the unfavorable prices. And another thing it can be an increase in the price of the substitute crop, hence farmers responded by switching their resources to the crop that will be more profitable soon. So, the farmers feel reluctant to grow potato, that's why the drop in the production of potato. The results are in consonance with (Rao, 2003), observation that the supply response is the reaction of the total yield and non-price factors, which mean a rise in price, farmers will allocate more resources to increase yield and a drop in price farmers will reduce the yield by decreasing the area allocated for production.

\section{Augmented Dickey Fuller (ADF) Unit Root Test}

The ADF method test the hypothesis that H0: $\mathrm{X} \sim 1(1)$, that is has unit root (non-stationary) against $\mathrm{H0}: \mathrm{X} \sim 1(0)$, that is, no unit root (stationary). The critical values for the rejection of the null hypothesis of unit root are all significant at 5\%. The results of the unit root tests showed that rainfall is stationary at levels, while others are not, nevertheless, as expected all the nonstationary series turn out to be stationary after first differencing. Therefore the null of the presence of unit root is accepted. However, the hypothesis of unit root in all series was rejected at $5 \%$ level of significance for all series after first difference. 
Table 6: The Unit Root Test results are presented in tables before and after differencing

\begin{tabular}{|l|c|l|c|l|}
\hline \multicolumn{1}{|c|}{ Log variables } & $\begin{array}{c}\text { ADF test } \\
\text { value }\end{array}$ & \multicolumn{1}{|c|}{ Decision } & $\begin{array}{c}\text { ADF test value at } \\
\text { first differencing }\end{array}$ & Decision \\
\hline Log area harvested & -1.67 & $\begin{array}{l}\text { Not } \\
\text { stationary }\end{array}$ & -7.417 & Stationary \\
\hline $\begin{array}{l}\text { Log production of } \\
\text { potato }\end{array}$ & -0.791 & $\begin{array}{l}\text { Not } \\
\text { stationary }\end{array}$ & -7.417 & Stationary \\
\hline Log price of potato & -1.76 & $\begin{array}{l}\text { Not } \\
\text { stationary }\end{array}$ & -10.432 & Stationary \\
\hline $\begin{array}{l}\text { Log price of sweet } \\
\text { potato }\end{array}$ & 0.161 & $\begin{array}{l}\text { Not } \\
\text { stationary }\end{array}$ & -5.828 & Stationary \\
\hline Log rainfall & -5.698 & Stationary & -5.698 & Stationary \\
\hline
\end{tabular}

Source: Own Survey, 2018

The Table 7 showed that price of potato was negatively insignificant to the production of the crop; this implied that a unit increase of potato price reduces the area harvested by -0.006 . The result indicated that the farmers didn't respond to a change in price of the crop, this might be a result of factor mobility and fixed cost and that price is not the only factor that can motivate farmers to react to supply, we also have the non-price factors like the good weather, improving technologies and institutional framework lead in the supply function. And that observation are in line with (Shoko, 2014), which reported that emerging countries presented that if farmers did not respond much to changes in enticements, it was not so much due to inability to adapt to changing circumstances but rather to the constraints they are facing. Moreover, higher prices variability and inconstancies in non-price factors all pose a risk to producer investment and these may be because the changes was not seen as profitable to the farmers hence that's why they didn't respond. Furthermore, the coefficient of price of sweet potato was positive and insignificant to the production of potato; this implied that a 1\% increase of sweet potato price increase the area allocation by 0.100 , this indicated that farmers responded positively to a change in price of sweet potato, through allocating area to produce sweet potato so that yield production increase, and to maximize profits. But, higher prices variability in substitute crops (sweet potato) poses a risk to the investment of the potato farmers. This suggests that farmers might be afraid to invest more on the sweet potato because they are not sure of the markets stability and consistency. These findings agree with Mamingi (1997) findings that agricultural supply mainly in the form of area expansion is determined by price and non- price factors. In addition to that a 1\% increase in the rainfall decrease the area harvested by -0.012 and it is not significant, these might be because farmers are not motivated by rainfall to respond to the potato production as potato are not a rain fed crop, hence rainfall doesn't motivate to respond to the supply of potato.

Table 7: Regression results for acreage response of potato to price and non-price factors

\begin{tabular}{|l|c|c|c|}
\hline Dependent variable (Area harvested) & Coefficients & $\mathrm{P}>\mathrm{t}$ & $\mathrm{R}^{2}$ \\
\hline Log price of potato & -0.0060847 & 0.919 & \\
\hline Log price of sweet potato & 0.1001778 & $0.022^{*}$ & \\
\hline Log rainfall & -0.0116109 & 0.780 & \\
\hline Cons & 7.721686 & 0.000 & \\
\hline & & & 0.7700 \\
\hline
\end{tabular}

Source: Own Survey, 2018

Significant at $5 \%$ level

The Table 8 displays the production results of the explanatory variables. The result showed that the coefficient of price of potato was positive and insignificant. This implied that a unit increase in the price of potato increase the production by 0.012 , the result indicated that 
farmers are responding positively to the production of potatoes as long prices are increasing, farmers will increase the production of potato and area allocation for production will be also increased. However, even if price can increase but farmers may respond in a small amount due to factors that are beyond the control of the farmers, such as fixed cost and factor mobility. The farmer may wish to responds significantly to change in price but may be limited by those factors, hence why the farmer's response was positive but was insignificant to a change in price of potato.

Moreover, the coefficient of price of sweet potato was positive and significant, this implied that a unit increase of price of sweet potato increase the production by 0.118 , these is an indication that an increase in price of sweet potato will motivate farmer to move their resources to the production of sweet potato in order to maximize profits. And the farmers are able to allocate the resources soon to respond to the price change in price of sweet potato, hence the result indicated that a substitute crop price change make motivate farmers to reallocate their resources to the production of sweet potato as it profitable move to take, that's why the farmers responded at the high amount and it significant. Also, the coefficient of rainfall is positive and insignificant; the result implied that a unit rise in the amount of rainfall during the production season will increase the production by 0.002 . Rainfall showed non-significant value due to the fact that potato is not a rain fed crop, which means farmers are not motivated to respond to the rainfall for production of crop hence that why it is insignificant. These observations, agrees with (Mamingi, 1997) that price provide incentive for farmers to increase production and agricultural supply mainly in the form of area expansion is determined by price and non-price factors.

Table 8: Regression results for production supply response of potato to price and non-price factors

\begin{tabular}{|l|c|c|c|}
\hline Dependent variable (Production) & Coefficients & $\mathrm{P}>\mathrm{t}$ & R-squared \\
\hline Log price of potato & 0.01230083 & 0.857 & \\
\hline Log price sweet potato & 0.1181702 & $0.016^{*}$ & \\
\hline Log Rainfall & 0.0022494 & 0.961 & \\
\hline Cons & 8.183924 & 0.000 & \\
\hline \multicolumn{3}{|c|}{ Significant at 5\% level } & 0.7700 \\
\hline Source: Own Survey, (2018) & & &
\end{tabular}

\section{CONCLUSION}

Base on the result of this study, price is one of the most influential factor motivating farmers to respond in supply of area harvested and increase production of the potato. And the price of the substitute also have a positive impact in terms of influencing farmers to react in a price change by responding with increase in area allocation to a price change, so that to increase the production. Also, prices are one of the most factors which provide farmers with incentives to increase yield production and area allocation, as long as prices are increasing, farmers will respond by increasing the area of production in order to stimulate the production, so that they maximize their profits.

\section{References}

Bonabana- Wabbi, J. A. (2013). The perfomance of potato markerts in South Western Uganda. Journal of Development and Agricultural Economics, 5(6), 225-235.

Dawson, M. A. (2002). Yield response in Pakistan agriculture.

Dlamini, N. A. (2012). The Impact of microeconomics policies on agriculture in Swaziland: An Empirical Anaysis. 
FAO. (2008). Evaluation of Mailard reaction in potato crips by acrylaminde, antoxidant capacity and color. Journal of food Consumption and Analysis.

FAOSTAT (2004). Agricultural Data . Provisional 2003 Production indices Data crop.

Hall, R. D. (2008). Plants metabolimics and its potential application for human nutrition. Physiologia plantarum 132, no. 2(2008): 162-175.

Horton, D. E. (1987). Potatoes: Production, marketing, and programs for developing countries. International Potato center.

Mamingi. (1997). Measuring the supply reponse function of tobacco in Zimbwabwe to price changes. a synthesis of available results. Agricultural Economics 16:17-34.

Mdluli. (2014). Factors contributing to low potato production in Swaziland: A case study of Motjane area. Unplublished Bsc Agriculture Thesis, University of Swaziland.

Okoboi. (2001). Determinants of smallholder farmers participation in the potato market in Kabale and Mbale. Third ruforum biennal- runforum.org.

Rahji, M. A.Y. (2008). Market supply response and demand for local rice in Nigeria: Implications for self sufficiency ploicy. Journal of Central European Agriculture, 9 (3), 567-573.

Xaba, B. M. (2012). An analysis of vegetables supply chain in Swaziland. Sustainable Agriculture Research, 2 (2),1. 